\title{
Globalization and Economic Development: The Nigerian Experience
}

\author{
Emmanuel Chike Onwuka ${ }^{1}$ and Agatha Eguavoen ${ }^{2}$ \\ 1. Department of Economics, 2. Department of Sociology, \\ Ambrose Alli University, Ekpoma, Nigeria \\ E-mail: <econwuka@yahoo.com><anteguavoen@yahoo.com>
}

KEYWORDS Globalization; market; competition; development; marginalization; indebtedness

\begin{abstract}
The world has witnessed increased interdependence in the last two decades, thanks to globalization. The main driving forces of this process are technology, policy and competition and it subordinates domestic economies to global market conditions and practices. Developed nations are the beneficiaries of globalization as their share of world trade and finance has been expanded at the expense of developing countries. Thus, the process exacerbates inequality between the world's regions and poverty in the developing world. Nigeria has not benefited from globalization due to monocultural export, inability to attract increased foreign investments and huge indebtedness. But globalization can be domesticated in the country through diversification of exports, debt reduction and expanded development cooperation with other countries. The Nigerian state also needs to be strengthened as a bulwark against the dictates of foreign capital. All this accomplished, Nigeria could join the league of nations enjoying the benefits of globalization.
\end{abstract}

\section{INTRODUCTION}

Over the past two decades, world output has been expanding and many countries are benefiting from increased cross-border trade and investments. Many others suffer because economic regimes are inefficiently managed, and this weakness reduces their capacity to successfully compete globally (Schneider and Enste, 2002). International mobility of capital, resulting from advances in communications technology and liberalization of financial markets has intensified as the world economy witnesses the unleashing of market forces. Deregulation of domestic markets, their opening to competition, privatization and the retreat of the state from economic management are also features of the current global order.

However, this same process encourages rising inequality among nations. The liberalization of the world economy, for instance, has proceeded in such a way that the growth prospects of developing countries are being undermined. Thus, while restrictions have been lifted on the freedom of capital and skilled labour to move to areas of high returns, the restrictions on the mobility of unskilled labour remain. Moreover, as developing countries have increased their capacity to produce and export manufactures, the developed countries have become active in promoting tariff peaks and escalations (UNCTAD, 2001a). Such measures can neither solve the South's development problems nor allow for a narrowing of the NorthSouth divide.

In this paper, we attempt an exploration of globalization and its implications for the growth process. The aim is to situate globalization in the context of Nigeria's development. To accomplish this task, the paper is separated into a number of sections. Apart from the introduction, section II provides an overview of trends in globalization. Section III addresses the impact of globalization on Nigeria's development while section IV contains the concluding remarks.

\section{AN OVERVIEW OF TRENDS IN GLOBALIZATION}

The world is fast becoming a global village, a metaphor that is often invoked to depict global interdependence and the increasing interaction among and the integration of economic activities of human societies around the world (Ajayi, 2001). In concrete terms, globalization is the intensification of cross-border trade and increased financial and foreign direct investment flows among nations, promoted by rapid advances in and liberalization of communication and information technology (Islam, 1999 and Aninat, 2002). Thus, globalization conjures the picture of a borderless world with greater economic integration that enhances the living standards of people across the globe. 
Even then, globalization is not a novelty in the development process. On the contrary, the late 19th century was a period of dramatic integration of the world economy as evidenced by the rapid expansion in world trade, the founding of the Latin Monetary Union in 1865 and the emergence of the gold standard in 1878 (Onwuka, 1998 and O'Rourke and Williamson, 1999). Although the retreat into managed trade by the major trading countries between the first and second world wars dampened the outlook of global economic intercourse, the post-1945 multilaterism has virtually permeated all corners of the globe.

Since 1990, increased economic cooperation has lifted the ratio of the growth of world export volume to the growth of gross world product to a range of 2.5-3 from an average of below 2 in the 1970s and 1980s (United Nations, 2001). Other benefits of globalization, which include exposure to new ideas and products, greater specialization and expanded opportunities for mergers and acquisitions, leading to growth in size and power of corporations, their increased competitiveness and efficiency in the utilization of productive resources and major improvements in social development and human welfare are well documented in the literature (see, for example, Ayorinde, et. al. 1998; Rodrik, 1999; Sachs, 2000; Crafts, 2000; Masson, 2001; IMF, 2002 and Ocampo, 2003). The transnational corporations (TNC) with their intensive integration of production, distribution and services globally provide the impetus for this process. Between 1990 and 2001, for instance, their stock of outward foreign direct investments (FDI) increased from 1.7 trillion dollars to 6.6 trillion dollars and in 2001 alone their sales of 19 trillion dollars were more than twice as high as world exports that year (UNCTAD, 2002a).

No doubt, increased trade and investment flows help countries to develop more quickly as trade generates income and the flows enable them to increase their stock of productive capital without compromising their level of consumption. And when such flows are in the form of FDI, they often improve access to international best practices in terms of managerial, marketing and technical know-how, skill acquisition and institutional deepening. Moreover, the intangible assets of TNC such as knowledge, technology, management know-how and market access serve not only as essential link between national economies, but also as a catalyst for investment and enterprise competitiveness as well as complements to domestic development resources in recipient countries (UNCTAD, 2001b).

Technology, policy and competition are the forces driving globalization. This is attested to, for example, by advances in computing technology, which enable traders to meet demand for financial instruments such as swaps and futures with relative ease, thus allowing them to better manage their risks. In addition, improved transportation such as the advent of containerization in land-and sea-based shipping has reduced both the handling requirements and transit time by more than two thirds. The second force is policy liberalization. With this, most governments have removed barriers to trade and controls on the movement of capital and services, thereby allowing market forces to play themselves out. The third force, which is heightened competition, compels firms to explore new ways of increasing their efficiency, including shifting some of their activities abroad to reduce costs (UNCTAD, 2002a).

However, not every nation is a full member of the global village. The developed countries use their competitive advantage to boost their share of world trade and finance, and so largely benefit from globalization (Khor, 2001 and UNCTAD, 2003a). On the other hand, developing countries are losing out as they experience a worsening of existing imbalances and distortions in the global economy (Collier and Dollar, 2001). This view is shared by Zuma (2003) who argues that the unequal distribution of political, economic and military power has meant that whilst globalization created immense opportunities of wealth for some, it has produced two contrasting global villages: one which is indeed prosperous, rich and democratic for a few who live in it, and the other, in which the majority are poor, alienated and marginalized with hardly any voice to determine their own destiny.

The data on tables 1 and 2 clearly show that there are actually two villages in the global economy. Table 1 reveals that developing countries are mainly primary commodity producers and exporters. In 1985, they accounted for 61.2 per cent of primary products traded globally. Although this dropped to 56 per cent in 2000 , this drop cannot compensate for the 68.2 per cent of manufactures based on natural resources or 66.8 per cent of manufacturers not 
based on natural resources that developed countries exported that year. The shares of developing countries in these categories of manufactures that same year were 26.6 per cent and 30.8 per cent respectively. In the case of FDI inflows (Table 2), developed nations increased their share from 64.4 per cent during 1990-1995 to 68.4 per cent in 2001 , whereas the share of developing countries fell from 33 per cent to 27.9 per cent during the same period.

Moreover, industrial countries protect their markets, particularly in sectors in which developing countries have a recognized comparative advantage like textiles, clothing and footwear. Agriculture is also heavily protected usually in the form of subsidies, driving world prices down and hurting farmers in developing countries the more. The estimate of economic losses from agricultural protection in developed countries is around 150 billion dollars yearly, about 50 billion dollars of it in lost exports for developing countries (for details, see McGuirk, 2002 and Lankas, 2002).

While responsibility for global economic reform is ceded to the International Monetary Fund and the International Bank for Reconstruction and Development (IMF/World Bank), the policies of these agents of globalization, controlled by the highly industrialized countries, have failed to narrow the gap between the richest 20 per cent of humanity and the poorest 20 per cent, which doubled between 1950 and 2000 (O' Rourke, 2002). Free trade and market forces, canvassed by globalization, are not closing this gap. Instead, they have contributed to widening it because after the Tokyo and Uruguay Rounds of trade liberalization in the 1980s and 1990s, the developing countries have ended up with 3 per cent more trade deficits and 2 per cent less economic growth in 2000 in comparison with the 1970s (Erb-Leoncarallo, 2000).

The economic internationalization process while not removing national sovereignty subordinates domestic economies to global market conditions (Kwanashie, 1998). The transmission of shocks this entails can alter the prospects of growth particularly in uncompetitive economies. In this respect, the economic fortunes of developing countries are hostage to the forces of globalization. The East Asian financial crisis of $1997 / 1998$ testifies to this assertion as the contagion, which followed affected the growth of many of them (UNCTAD, 1999; Bresciani et al., 2002).

As we acknowledge the peculiar economic circumstances of developing countries, we also share the view canvassed by Onimode (2003) that the desirable policies for them even in the context of globalization are those that promote selfreliance. This becomes imperative after the fact that globalization increases their dependence on foreign capital and the attendant exploitation impedes their growth, aggravates their poverty and intensifies their marginalization in the global economy. The message from these concerns is that globalization is more than the free interplay of market forces since economic questions cannot be divorced from social issues. That being the case, the foundation of globalization has to be strengthened with broadly shared values and practices that would also reflect the needs of developing regions, so that all countries could benefit from the globalization process.

\section{Globalization and Nigeria's Economic Development}

Globalization is a very uneven process with unequal distribution of its benefits and losses. This imbalance leads to polarization between the developed countries that gain, and the developing countries that lose out (Obadan, 2001). In this regard, the place of Nigeria in the globalization agenda requires some in-depth study. To begin with, Nigeria is economically weak due to inadequate domestic economic capacity and social infrastructure needed to boost the country's productivity, growth and competitiveness. Secondly, the economy is made weaker by monocultural dependency and unfavourable terms of trade in its export trade as well as excruciating debt and debt service burdens. And thirdly, before 1986, economic regimes were regulated and the country pursued expansionary fiscal and monetary policies in its development efforts (Obadan, 1998). These problems were exacerbated by political instability and corruption. As a result, investment choices were distorted, which eroded the confidence especially of foreign investors.

Following the globalization trend, Nigeria has been liberalizing its economy. But the real sectors have had to function under conditions of unstable macroeconomic management, inadequate technology and credit facilities. These have 
Table 1: The structure of world trade in major product categories, by region $1985-2000^{\mathrm{a}}(\%)$

\begin{tabular}{|c|c|c|c|c|c|c|}
\hline & \multicolumn{2}{|c|}{ Primary Products } & \multicolumn{2}{|c|}{$\begin{array}{l}\text { Manufactures Based } \\
\text { on Natural Resources }\end{array}$} & \multicolumn{2}{|c|}{$\begin{array}{r}\text { Manufactures not Based } \\
\text { on Natural Resources } \\
\end{array}$} \\
\hline & 1985 & 2000 & 1985 & 2000 & 1985 & 2000 \\
\hline Developed Countries ${ }^{b}$ & 38.0 & 40.4 & 68.7 & 68.2 & 81.9 & 66.8 \\
\hline Central \& Eastern Europe ${ }^{b}$ & 0.8 & 3.6 & 1.4 & 5.2 & 0.6 & 2.4 \\
\hline Developing Countries $^{\mathrm{b}}$ & 61.2 & 56.0 & 29.8 & 26.6 & 17.5 & 30.8 \\
\hline East \& South East Asia & 10.4 & 9.5 & 8.4 & 11.7 & 10.8 & 22.6 \\
\hline Latin America \& Caribbean & 12.5 & 13.2 & 7.0 & 6.5 & 2.6 & 4.6 \\
\hline Middle East \& North Africa & 21.4 & 20.9 & 4.9 & 3.9 & 0.8 & 1.1 \\
\hline South Asia & 1.2 & 1.2 & 0.8 & 1.4 & 0.6 & 1.0 \\
\hline Sub-Saharan Africa & 5.4 & 4.3 & 1.7 & 1.3 & 0.4 & 0.2 \\
\hline
\end{tabular}

a. Based on three-year average for 1985 (1984-1986) and two-year average for 2000 (1999-2000).

b. These three regions add up to 100 per cent for each export category.

Source: UNCTAD 2002. World Investment Report 2002: Transnational Corporations and Export

Competitiveness, Geneva: United Nations, p. 148.

Table 2: Foreign direct investment inflows by host region (million dollars and \%)

\begin{tabular}{lrrrrrrr}
\hline Host Region & \multicolumn{7}{c}{ Annual Average } \\
\cline { 2 - 8 } & $1990-1995$ & 1996 & 1997 & 1998 & 1999 & 2000 & 2001 \\
\hline World & 225321 & 386140 & 478082 & 694457 & 1088263 & 1491934 & 735146 \\
& $(100)$ & $(100)$ & $(100)$ & $(100)$ & $(100)$ & $(100)$ & $(100)$ \\
Developed economies & 145019 & 219908 & 267947 & 484239 & 837761 & 1227476 & 503144 \\
& $(64.4)$ & $(57.0)$ & $(56.0)$ & $(69.7)$ & $(77.0)$ & $(82.3)$ & $(68.4)$ \\
Developing economies & 74288 & 152685 & 191022 & 187611 & 255140 & 237894 & 204801 \\
& $(33.0)$ & $(39.5)$ & $(40.0)$ & $(27.0)$ & $(20.7)$ & $(15.9)$ & $(27.9)$ \\
Central \& Eastern Europe & 6014 & 13547 & 19113 & 22608 & 25363 & 26563 & 27200 \\
& $(2.7)$ & $(3.5)$ & $(4.0)$ & $(3.3)$ & $(2.3)$ & $(1.8)$ & $(3.7)$ \\
\hline
\end{tabular}

The figures in parenthesis are in percentage and calculated by the author.

Source: UNCTAD 2002. World Investment Report 2002: Transnational Corporations and Export

Competitiveness, Geneva: United Nations, pp. $303-305$.

proved to be an obstacle to strengthening the productive base, especially of agriculture and industry, in order to make them export-oriented. Thus, in spite of the openness of the economy, external trade performance has not been encouraging as table 3 bears witness.

A study of table 3 shows that oil exports dominate Nigeria's foreign trade, accounting for more than 80 per cent of exports during the years under consideration. Food, agricultural raw materials and manufactures accounted for only 1 per cent of total export in 1990, but this fell to 0 per cent in 2000. In between that period, the country never exported ores and metals (World Bank, 2002). As a monocultural exporter, over 80 per cent of Nigeria's exports is made up of crude petroleum. But instability in the world oil market sometimes negatively affects oil exports, leading in such circumstances to declines in foreign exchange earnings as is shown in table 3 . This partly explains the country's recourse to external funding in order to meet its development challenges.
But external borrowing exposes Nigeria to indebtedness, which reached 29.8 billion dollars in 2002. The servicing of this debt depleted the national treasury by 1.2 billion dollars out of 10.7 billion dollars foreign exchange earned that year (Central Bank of Nigeria, 2002). Even more worrisome is the ratio of this debt to gross domestic product (GDP) and export earnings. In 1985, the total debt stock was 710 billion naira, which corresponded to 1 per cent and 6 per cent of GDP and export earnings respectively. In 2001, the country's external debt had risen to 3.2 trillion naira, which was 56 per cent of GDP and 633 per cent of export earnings (see Table 4).

Financial market liberalization, also exposes the country to volatility and shocks. Yet, access to credits is granted to the country under strict conditionalities. Moreover, the shortfalls in servicing Nigeria's debt have led Export Credit Guarantee Agencies (ECGA) to suspend insurance cover for export of goods, services and investment to the country. Nigerian importers are also required to provide 100 per cent cover for all 
Table 3: Foreign trade of Nigeria 1985 - 2001 (billion Naira)

\begin{tabular}{|c|c|c|c|c|c|c|c|c|}
\hline \multirow[b]{2}{*}{ Year } & \multicolumn{2}{|c|}{ Imports } & \multicolumn{2}{|c|}{ Exports } & \multicolumn{2}{|c|}{ Total Trade } & \multicolumn{2}{|c|}{ Balance of Trade } \\
\hline & Oil & Non Oil & Oil & Non Oil & Oil & Non Oil & Oil & Non Oil \\
\hline 1985 & 51.8 & $7,010.80$ & $11,223.70$ & 497.1 & $11,275.50$ & $7,507.90$ & $11,171.90$ & $6,513.70$ \\
\hline 1986 & 913.9 & $5,069.70$ & $8,368.50$ & 552.1 & $9,282.40$ & 5621.8 & $7,454.60$ & $4,517.60$ \\
\hline 1987 & $3,170.10$ & 14691.6 & $28,208.60$ & 2152 & $31,378.70$ & $16,843.60$ & $25,038.50$ & $12,539.60$ \\
\hline 1988 & $3,803.10$ & 17642.6 & $28,435.40$ & 2757.4 & $32,238.50$ & $20,400.00$ & $24,632.30$ & $14,885.20$ \\
\hline 1989 & $4,671.60$ & $26,188.60$ & $55,016.80$ & 2954.4 & $59,688.40$ & $29,143.00$ & $50,345.20$ & $23,234.20$ \\
\hline 1990 & 60,731 & $39,644.80$ & $106,626.50$ & 3259.6 & $112,699.60$ & $42,904.40$ & $100,553.40$ & $36,385.20$ \\
\hline 1991 & $7,595.30$ & $79,424.90$ & $116,858.10$ & 4677.3 & $124,453.40$ & $84,102.20$ & $109,262.80$ & $74,747.60$ \\
\hline 1992 & $19,937.20$ & $125,974.20$ & $203,292.70$ & 3973.3 & $233,229.90$ & $129,947.50$ & $183,355.50$ & $122,000.90$ \\
\hline 1993 & $41,329.30$ & $124,771.10$ & $213,778.80$ & 4991.3 & 255108.1 & $129,762.40$ & $172,449.50$ & $119,779.80$ \\
\hline 1994 & $42,349.60$ & $120,439.20$ & $200,710.20$ & 5349 & 243059.8 & $125,788.20$ & $158,360.60$ & $115,090.20$ \\
\hline 1995 & $155,825.90$ & $599,301.80$ & $927,565.30$ & $23,096.10$ & $1,083,391.20$ & $622,397.90$ & $771,739.40$ & $576,205.70$ \\
\hline 1996 & $162,178.70$ & $400,447.90$ & $1,286,215.90$ & $23,327.50$ & $1,448,394.60$ & $423,775.40$ & $1,124,037.20$ & $377,120.40$ \\
\hline 1997 & $166,902.50$ & $678,814.10$ & $1,212,499.40$ & $29,163.30$ & $1,379,401.90$ & $707,977.40$ & $1,045,596.90$ & $649,650.80$ \\
\hline 1998 & $175,854.20$ & $661,564.50$ & $717,786.50$ & $34,070.20$ & $893,640.70$ & $695,634.70$ & $541,932.30$ & $627,494.30$ \\
\hline 1999 & $211,671.30$ & $650,836.00$ & $1,169,508.50$ & $19,498.00$ & $1,381,179.00$ & $670,334.00$ & $957,837.20$ & $631,338.00$ \\
\hline 2000 & $51,317.40$ & $121,740.80$ & $565,652.70$ & 6197.4 & $616,970.00$ & 127938.3 & $514,335.30$ & $115,543.40$ \\
\hline 2001 & $61,258.10$ & $248,802.20$ & $495,021.10$ & 6602.5 & $556,280.30$ & $255,404.70$ & $433,764.10$ & $242,199.70$ \\
\hline
\end{tabular}

Table 4: Selected economic indicators of Nigeria 1985 - 2001

\begin{tabular}{lccccrrr}
\hline Year & $\begin{array}{c}\text { GDP million (\#) } \\
\text { At current }\end{array}$ & $\begin{array}{c}\text { GDP Growth } \\
\text { rate (\%) }\end{array}$ & $\begin{array}{c}\text { External Debt } \\
\text { (\#) million }\end{array}$ & $\begin{array}{c}\text { External Debt } \\
\text { GDP ratio }(\%)\end{array}$ & $\begin{array}{c}\text { Total Export } \\
\text { (\#) million }\end{array}$ & $\begin{array}{c}\text { Growth rate } \\
\text { of Export }\end{array}$ & $\begin{array}{c}\text { External Debt } \\
\text { Export ratio }(\%)\end{array}$ \\
\hline 1985 & 72355.4 & 13.8 & 710.7 & 1 & $11,720.80$ & 29 & 6.1 \\
1986 & 73061.9 & 1 & - & - & $8,920.60$ & -23.9 & - \\
1987 & 108885.1 & 49 & 3912.3 & 3.6 & $30,360.60$ & 240.3 & 12.8 \\
1988 & 145243.3 & 33.4 & 3915.6 & 2.7 & $31,192.80$ & 2.7 & 12.6 \\
1989 & 224796.9 & 54.8 & 8820 & 3.9 & $57,971.20$ & 85.8 & 15.2 \\
1990 & 260636.7 & 15.9 & 1176 & 4.5 & $109,886.10$ & 89.5 & 10.7 \\
1991 & 324010 & 24.3 & - & - & $121,535.40$ & 10.6 & - \\
1992 & 549808.8 & 69.7 & - & - & $207,266.00$ & 70.5 & - \\
1993 & 697090 & 26.8 & 40500 & 5.8 & $218,770.10$ & 5.6 & 18.5 \\
1994 & $914,940.00$ & 31.3 & 39600 & 4.3 & $206,059.20$ & 5.8 & 19.2 \\
1995 & $1,977,740.00$ & 116.2 & 44000 & 2.2 & $950,661.40$ & 361.4 & 4.6 \\
1996 & 2823900 & 42.8 & 44000 & 1.6 & $1,309,543.40$ & 37.7 & 3.4 \\
1997 & $2,939,650.00$ & 4.1 & 44000 & 1.5 & $1,241,662.70$ & -5.2 & 3.5 \\
1998 & $2,881,310.00$ & -2 & 633017 & 22 & $751,856.70$ & -39.4 & 84.2 \\
1999 & 3352650 & 16.4 & $2,577,383.40$ & 76.9 & $189,006.50$ & 58.1 & $2,6.8$ \\
2000 & 4980943 & 48.6 & $3,097,383.80$ & 62.2 & $571,850.10$ & -51.9 & 450.7 \\
2001 & 5639865 & 13.2 & $3,176,291.00$ & 56.3 & $501,624.70$ & -12.2 & 633.2 \\
\hline
\end{tabular}

Source: Central Bank of Nigeria Statistical Bulletin (Various Issues), Abuja: Central Bank of Nigeria; Central Bank of Nigeria Annual Report and Statement of Accounts (Various Issues), Abuja: Central Bank of Nigeria.

their order. As such, they are placed at competitive disadvantage to those who have access to ECGA covers and import credit facilities (Debt Management Office, 2001). This situation exacerbates the pains of the external debt and hampers the inflow of foreign resources needed for the stimulation of investment and growth.

FDI inflows to Nigeria amounted to 588 million dollars in 1990. This rose to 1,079 million dollars in 1995, but declined to 930 million dollars in 2000 (UNCTAD, 2002b). Worldwide FDI in 2001 were 823.8 billion dollars and Nigeria attracted only 1.1 billion dollars or 0.13 per cent of that amount. Although global FDI declined to 651.2 billion dollars in 2002, Nigeria increased her share to 0.19 per cent of such investments as she attracted 1.3 billion dollars of FDI that year (UNCTAD, 2003b). However, that share is meager and it is explained by the peripheral position of the country in the financial and profit calculations of industrialized nations and the country's marginalized status within the orbit of modern capitalism.

In discussing globalization vis-à-vis Nigeria's development, two issues deserve consideration. The first relates to the Washington consensus and the second concerns the wisdom of opening the economy to international monopoly capitalism. In addressing these issues, we observe 
that the IMF/World Bank and their Western collaborators are satisfied with the peripheral role of Nigeria as an exporter of raw materials, especially crude petroleum, to and importer of manufactured goods from the West. In this connection, Stewart (2002) maintains that the capitalist need to sustain the import capacity of peripheral economies in order to facilitate continued production and maximize profits at the center explains why in the periphery countries raw material exports are encouraged. In that event foreign exchange receipts are low, which makes external loan contraction inevitable for social and economic development. Nigeria is no exception to this rule. But then, contracted debts due for repayment, which the country cannot actually pay, are only being reprogrammed, not written off because their continued servicing helps to maintain financial stability at the center.

But globalization can be of immense benefit to Nigeria and so could help the country's development. The enabling framework would include measures to ensure the entry of Nigeria's non-oil exports into the core markets without discrimination. In this regard, the diversification of domestic production is imperative. The unsustainable debt, which weighs the country down economically also needs to be tackled with faster and deeper debt relief by developed nations, while expanded development cooperation with them would strengthen the productive base of the Nigerian economy. The international financial architecture also requires to be broadened and deepened through global solidarity that would see increased inflows of foreign investments into the country. This accomplished, globalization would contribute to enhancing the living standards of Nigerians as the country joins the league of nations enjoying the benefits of that process.

\section{CONCLUDING REMARKS}

The profit-seeking market economy has spread globally and in the process demonstrated its efficiency and dynamism. This global outlook has been made possible by progressive dismantling of barriers to trade and capital mobility, fundamental technological advances and steadily declining costs of communication, transportation and computing. The integrative logic of globalization, therefore, seems inexorable and its momentum is irresistible. But the opportunities of this global system of interaction remain highly concentrated among the industrialized countries to the exclusion of the majority of developing nations. There is also anxiety that the sovereignty of states is at stake as globalization appears to question their rights to independent decision-making.

Creating an inclusive global market is the major challenge of globalization. In this respect, the industrialized nations must choose between a global market driven only by calculations of profit and one, which offers prosperity to all countries through the instrumentally of global economic solidarity. That solidarity is needed with developed nations opening their markets, providing deeper and faster debt relief and giving more and better-focused development assistance to developing countries. As the "market juggernaut" is rolling at full steam, new pragmatic approaches to development challenges, consistent with interdependent actions are equally needed in order to bridge the North-South divide and place globalization at the service of justice and prosperity for all nations.

Nigeria supports the economic openness that globalization preaches and bears its burdens. But the authority of the Nigerian state in economic management has to be strengthened as a bulwark against the notion that entirely unfettered markets are indispensable for development to occur. Such an ideological conceit if not questioned could weaken efforts at domesticating globalisation for economic development in the country. The East Asian "tigers" have not followed blindly the prescriptions of the Washington consensus since their governments play important economic roles than the Western nostrums advise (Stiglitz, 2000). The Nigerian government can benefit from that experience as the country pursues development within the context of globalization.

\section{REFERENCES}

Ajayi, S.I. 2001. "What Africa Needs to Do to Benefit From Globalization." Finance and Development, 38 (4): $6-8$.

Aninat, E. 2002. "Surmounting the Challenges of Globalization." Finance and Development, 39 (1): 4-7.

Ayorinde, F.O., O. Adenikinju and A. Adenikinju. 1998. "The Impact of Trade Liberalization on Technological Acquisition in Nigerian Manufacturing Sector." Journal of Economic Management, 5 (2): 89-122.

Bresciani, F., G. Feder, D.O. Gilligan, H.G. Jacoby, T. Onchan and J. Quizon. 2002. "Weathering the Storm: 
The Impact of the East Asian Crisis on Farm Households in Indonesia and Thailand." The World Bank Research Observer, 17(1): 1-20.

Central Bank of Nigeria 2002. Annual Report and Statement of Accounts for the Year Ended 31st December, 2002. Abuja: Central Bank of Nigeria.

Collier, P. and D. Dollar. 2001. Globalization, Growth and Poverty: Building an Inclusive World Economy. Oxford: Oxford University Press.

Crafts, N. 2000. "Globalization and Growth in the Twentieth Century." IMF Working Paper No. 44, Washington: International Monetary Fund.

Debt Management Office 2001. Annual Report and Statement of Accounts for the year Ended 2001. Abuja: Debt Management Office.

Erb-Leoncarallo, A.M. 2000. "The Road From Seattle," in United Nations Chronicle Vol. XXXVII, No. 1, New York: Department of Public Information, United Nations.

IMF 2002. Globalization: Threat or Opportunity? Issues Briefs. Washington: International Monetary Fund.

Islam, A. 1999. "Globalization and Development Revisited in the Light of Asian Experience." Asia Pacific Development Journal, 6(2): 1 - 21.

Khor, M. 2001. Globalization and the South: Some Critical Issues. Ibadan: Spectrum Books.

Kwanashie, M. 1998. "The Concept and Process of Globalization." Central Bank of Nigeria Economic and Financial Review, 36(4): 340 - 351.

Lankas, H.P. 2002. "Market Access for Developing Countries." Finance and Development, 39(3): 8-13.

Masson, P. 2001. "Globalisation: Facts and Figures." IMF Policy Discussion Paper No. 4, Washington: International Monetary Fund

McGuirk, A. 2002. "The Doha Development Agenda." Finance and Development, 39(3): 4 - 7.

Obadan, M. I. 1998. "Managing the Nigerian Economy into the Next Millennium: Strategies and Policies." Journal of Economic Management, 5(1): 1 - 38

Obadan, M. I. 2001. "Africa and the Challenge of Globalization: How Should the Continent Respond?" Nigerian Journal of Economic and Financial Review, 6(2): 35-42.

Ocampo, J. O. 2003. Globalization and Development, Washington: The World Bank.

Onimode, B. 2003. "Unequal Exchange, External Debt and Capacity for Development-Oriented Policies in African Countries", (pp. 39-56) in A. Garba (ed.), Development Thought, Policy Advice and Economic Development in Africa in the 20th Century: Lessons for the 21st Century: Ibadan: Ibadan University Press.

Onwuka, E.C. 1998. Contemporary International Economic Relations, Benin: Razjel Interbiz Group.

O'Rourke, H. and J.G. Williamson. 1999. Globalization and History: The Evolution of a Nineteenth Century Atlantic Economy, Cambridge: MIT Press.
O'Rourke, K. H. 2002. "Globalization and Inequality: Historical Trends", (pp. 39-67) in B. Pleskovic and N. Stern. (ed.), Annual World Bank Conference on Development Economics 2002: Washington: The World Bank.

Rodrik, D. 1999. "The New Global Economy and Developing Countries: Making Openness Work." Policy Essay No. 24, Washington: Overseas Development Council.

Sachs, J. 2000. "A New Global Consensus of Helping the Poorest of the Poor", (pp. 39-47) in B. Pleskovic and N. Stern, (eds.), Annual World Bank Conference on Development Economics 2000: Washington: The World Bank.

Schneider, F. and D. Enste. 2002, Hiding in Shadows: The Growth of the Underground Economy, Washington: International Monetary Fund.

Stewart, T. 2002. The Third World Debt Crisis: A Continuity of Imperialism, Geneva: The South Centre.

Stiglitz, J.E. 2000. "Development Thinking at the Millennium", (pp. 13-38) in B. Pleskovic and N. Stern (eds.), Annual World Bank Conference on Development Economics 2000: Washington: The World Bank.

UNCTAD. 1999. "International Monetary and Financial Issues for the 1990s." Research Papers for the Group of Twenty-Four, Vol. XI, Geneva: United Nations.

UNCTAD. 2001a. Post-Uruguay Round Market Access Barriers for Industrial Products, Policy Issues in International Trade and Commodities Study Series No. 12. Geneva: United Nations.

UNCTAD. 2001b. World Investment Report 2001: Promoting Linkages. Geneva: United Nations.

UNCTAD. 2002a. World Investment Report 2002: Transnational Corporations and Export Competitiveness. Geneva: United Nations.

UNCTAD. 2002b. UNCTAD Handbook of Statistics 2002. Geneva: United Nations.

UNCTAD. 2003a. Trade and Development Report 2003: Capital Accumulation, Growth and Structural Change. Geneva: United Nations.

UNCTAD. 2003b. World Investment Report 2003: FDI Policies for Development - National and International Perspectives. Geneva: United Nations.

United Nations. 2001. World Economic and Social Survey 2001: Trends and Policies in the World Economy. New York: Department of Economic and Social Affairs, United Nations.

World Bank 2002. World Development Indicators 2002. Washington: The World Bank.

Zuma, N.D. 2003. NEPAD's Peer Review Mechanism. Available Online at http://www.sarpn.org.za/ documents/d0000564/index.php. 